\title{
Memorializing Soldiers or Celebrating Westward Expansion: Civil War Commemoration in Sioux City and Keokuk, 1868-1938
}

\author{
TONY KLEIN
}

TO RESIDENTS of Sioux City and Keokuk in the late nineteenth and early twentieth century, Civil War commemoration was a celebration of Union victory and a tribute to veterans who served or died in the war. For Sioux City, however, it was also a way for citizens to celebrate their community's growth and incorporation into the American nation. Civil War commemoration provided western cities founded shortly before or after the Civil War, like Sioux City, the rituals, symbols, myths and narratives that were vital to becoming part of the nation. While usually echoing the same themes as the rest of the country, Sioux City residents also constructed a narrative in which one result of the Civil War was to open the West to industrious and freedom-loving people. Thus, to Sioux City citizens concerned with their role in the Civil War, their community's success in the post-Civil War years became part of the war's legacy.

I thank Dr. John Neff at the University of Mississippi for his guidance and for encouraging me to pursue publication of this article. I also thank Marvin Bergman, anonymous readers for the Annals of Iowa, and many friends, family, colleagues, and students who read drafts of this article. Finally, I thank my mother, Janeene, at the Remsen Public Library and staff at the State Historical Society of Iowa, Iowa Library Services, Sioux City Public Museum, and Keokuk Public Library for their research assistance.

THE ANNALS OF IOWA 71 (Fall 2012). (C) The State Historical Society of Iowa, 2012. 
The importance of Civil War commemoration in Keokuk was different because the city had played a more significant role in the war than Sioux City had. Civil War commemoration was a way for citizens of Keokuk to remember and mourn the dead, honor surviving veterans, and celebrate the city's Civil War history.

Because of the magnitude of the Civil War, historians have searched for national patterns of commemoration and memory. Keokuk's and Sioux City's Memorial Day observances, hosting of state Grand Army of the Republic (GAR) encampments, and monument building reflected national trends but also revealed the different ways each community remembered its role in the war. ${ }^{1}$ Keokuk generally fits into the national patterns of commemoration and provides an example with which to juxtapose the unique aspects of Sioux City's remembrance of the war. Residents of Sioux City, while displaying similar tendencies in their commemorations, added a western narrative that historians of Civil War memory have overlooked.

The neglect of a western vision in the historiography is evident in David W. Blight's Race and Reunion: The Civil War in American Memory, where he argues that there are three primary visions of Civil War memory. First, he identifies a reconciliationist vision in which veterans and citizens in the North and South put aside sectional differences in order to heal Civil War wounds. After 1890, this vision of Civil War memory was an important, though not dominant, theme in both Keokuk and Sioux City commemorations. ${ }^{2}$ Blight's other two visions, eman-

1. I use the term Memorial Day to refer to specific commemorations after 1885 and Decoration Day for 1885 and before. David W. Blight, in Race and Reunion: The Civil War in American Memory (Cambridge, MA, 2001), 97, notes that the name Memorial Day came to replace Decoration Day in the 1880s. The shift can be seen in the interchangeable use of the terms in Keokuk and Sioux City newspapers. In its edition of May 31, 1884, the Sioux City Journal (SCJ) used Decoration Day in a headline and Memorial Day in the text of the article. Conversely, the May 31, 1885, edition of the Keokuk Daily Gate City (KDGC) had a headline with Memorial Day in it, but used the term Decoration Day throughout the article. Sioux City papers employed Memorial Day almost exclusively from 1885 and later. Keokuk papers used the terms interchangeably until 1890, when Memorial Day became the common nomenclature.

2. Blight, Race and Reunion, 2. For another reconciliationist interpretation, see Nina Silber, The Romance of Reunion: Northerners and the South, 1865-1900 (Chapel Hill, NC, 1993). 
cipationist and white supremacist, are trends that were also present in Keokuk and Sioux City, but appear in their Civil War commemorations only implicitly and infrequently. ${ }^{3}$

Other historians of Civil War memory have identified additional trends, but they, too, have ignored western communities. John Neff focuses on Northern and Southern memory, but unlike Blight, he argues that postwar reconciliation was not dominant. Neff believes, instead, that the "clearest evidence of a persistent divergence in American society - of a lack of reconciliation-is found in the commemoration of the war's soldier dead." Confirming Neff's observation, citizens of Sioux City and, even more, Keokuk resisted reconciliation with their Confederate foes. ${ }^{4}$

3. Blight, Race and Reunion, 2. For a description of the emancipationist vision expressed and celebrated in Iowa, see Leslie A. Schwalm, "Emancipation Day Celebrations: The Commemoration of Slavery and Freedom in Iowa," Annals of Iowa 62 (2003), 291-332. According to Schwalm, southeastern Iowa and Keokuk had a vibrant African American community that celebrated Emancipation Day until World War II. Another example comes from the May 30, 1939, edition of the KDGC, which ran a story about John Draine, a 95-year-old ex-slave, who was Keokuk's last surviving Civil War veteran. Draine, however, spent most of his life after the Civil War in Jefferson City, MO. White supremacy was more common in Sioux City. William L. Hewitt, in "So Few Undesirables: Race, Residence, and Occupation in Sioux City, 1890-1925," Annals of Iowa 50 (1989/1990), 160, described Sioux City whites as "dissent[ers] from the extreme manifestations of Negrophobia. . . . Few of them questioned the assumption that blacks were inferior to whites or that they should remain separate ... [but] they still regarded their relationships with black people as more just and progressive than southern race relations." Additional evidence of white supremacy in Sioux City was the popularity of blackface minstrel shows. See Hewitt, "Blackface in the White Mind: Racial Stereotypes in Sioux City, Iowa, 1874-1910," Palimpsest 71 (1990), 68-79. Rare occasions of white supremacy in Civil War commemoration were in the speeches of J. D. O. Powers in 1902 (SCJ, 5/31/1902) and Judge J. S. Lawrence in 1905 (SCJ, 5/31/1905).

4. John Neff, Honoring the Civil War Dead: Commemoration and the Problem of Reconciliation (Lawrence, KS, 2005), 5. Other themes in Civil War memory are identified by Stuart McConnell, Glorious Contentment: The Grand Army of the Republic, 1865-1900 (Chapel Hill, NC, 1992), who suggests that Union veterans, who wanted to reconstruct prewar society, used Civil War memory to exclude blacks, women, immigrants, and the working class from the postwar political and public world; and Gary Gallagher, who, in The Union War (Cambridge, MA, 2011) and Causes, Won, Lost, and Forgotten: How Hollywood and Popular Art Shape What We Know about the Civil War (Chapel Hill, NC, 2008), emphasizes the idea of Union as the motivating factor among citizens of Union states who fought in and supported the Civil War. 
William C. Lowe, in a recent article on the Iowa Civil War monuments tour of 1906, tries to make sense of the various visions of Civil War memory. During Iowans' tour to dedicate Civil War monuments in battlefields in the South, Iowa dignitaries demonstrated elements of all of the themes present in Civil War memory nationally: reconciliation, anti-reconciliation, celebration, preservation of the Union, and restoration of Union veterans' worldview. In addition, Iowans on the monuments tour emphasized that the "young state of Iowa had more than done its part" in the Civil War. ${ }^{5}$

Lowe's observation of Iowans' desire to commemorate service in the Civil War highlights the differences between Keokuk and Sioux City. Keokuk residents had clear evidence that their city had "done its part" and could draw on that experience during commemorations. Keokuk could be proud that its young men had fought in the Civil War. In addition, most Iowa regiments had mustered in the city before departing for the war, and its residents had nursed Union soldiers back to health in the city's several war hospitals and honorably buried those who did not survive. Sioux City, in contrast, had almost no impact on the war between the Union and Confederacy because it was a village oriented toward the West during the 1860s. Its residents could not claim that their city was vital to the war's outcome, so they needed some other way to praise their community during Memorial Day ceremonies, GAR encampments, and monument dedications. To do so, they claimed that one of the reasons the Civil War was fought was so that liberty-seeking and patriotic people like themselves could move west to Sioux City and prosper.

BEFORE THE CIVIL WAR, Keokuk boosters envisioned their city as another Chicago or St. Louis because of its location at the confluence of the Des Moines and Mississippi rivers. In the early 1850s Keokuk boomed because it was well positioned to control the vast agricultural produce of Iowa's interior. If steamboats had remained the primary vehicle of commerce, then perhaps the city would have continued to grow in size and importance, but railroads and bridges over the Mississippi undercut the im-

5. William C. Lowe, "'A Grand and Patriotic Pilgrimage': The Iowa Civil War Monuments Dedication Tour of 1906," Annals of Iowa 69 (2010), 43-50. 
portance of Mississippi River towns. The Panic of 1857 stunted Keokuk's growth at around 15,000 residents, where its population remained until declining in the past few decades. In the late 1850s Keokuk went from being an active river port to a place that represented the bust of the economic crisis of the late 1850s. By 1861, residents of Keokuk, despite their best efforts to reverse the town's fortunes, had little reason to feel pride or confidence. ${ }^{6}$

The Civil War gave new energy to Keokuk, which played a more important role in the war than any other city in the state. Because of its location, it became home to four army camps, and many of the state's regiments mustered in and embarked from Keokuk. It was an important hospital center for the Union, eventually supporting six hospitals and treating tens of thousands of troops during the war. The largest of the hospitals was the Estes House, which later served as the local GAR posts' headquarters until the 1910s. Because of the hospital presence, the federal government created Iowa's only National Cemetery in Keokuk in 1862. After the war, the Estes House and the National Cemetery remained visible physical reminders of Keokuk's participation in the war. No comparable symbols were present in Sioux City. ${ }^{7}$

Because Keokuk played an important role for the state of Iowa in the Civil War, it was among the first cities in the state to celebrate Decoration Day, doing so in $1868 .{ }^{8}$ On May 30, the

6. See Michael A. Ross, "Cases of Shattered Dreams: Justice Samuel Freeman Miller and the Rise and Fall of a Mississippi River Town," Annals of Iowa 57 (1998), 201-39.

7. For the importance of public places for creating memory, see Pierre Nora, "Between Memory and History: Les Lieux de Memoire," Representations 26 (1989), 7-24; and G. Kurt Piehler, Remembering War the American Way (Washington, DC, 1995). For background on Keokuk's role in the Civil War and early observances of Memorial Day, see William J. Petersen, "Memorial Day," Palimpsest 49 (1968), 164-65. There is a plaque in downtown Keokuk where the Estes House once stood. See KDGC, 4/4/1928.

8 . The proceedings and speeches delivered on Memorial Day were important because they provided an annual opportunity for citizens to reflect on the meaning of the Civil War. Blight, Race and Reunion, devotes an entire chapter, "Decoration Days," 64-97, to Memorial Day as a source of Civil War memory. Others who emphasize Memorial Day as a source of memory include James M. Mayo, War Memorials as Political Landscape: The American Experience and Beyond (New York, 1988), 51-53; Neff, Honoring the Civil War Dead, 136-40; and Piehler, Remembering War, 6-7, 57-60. 


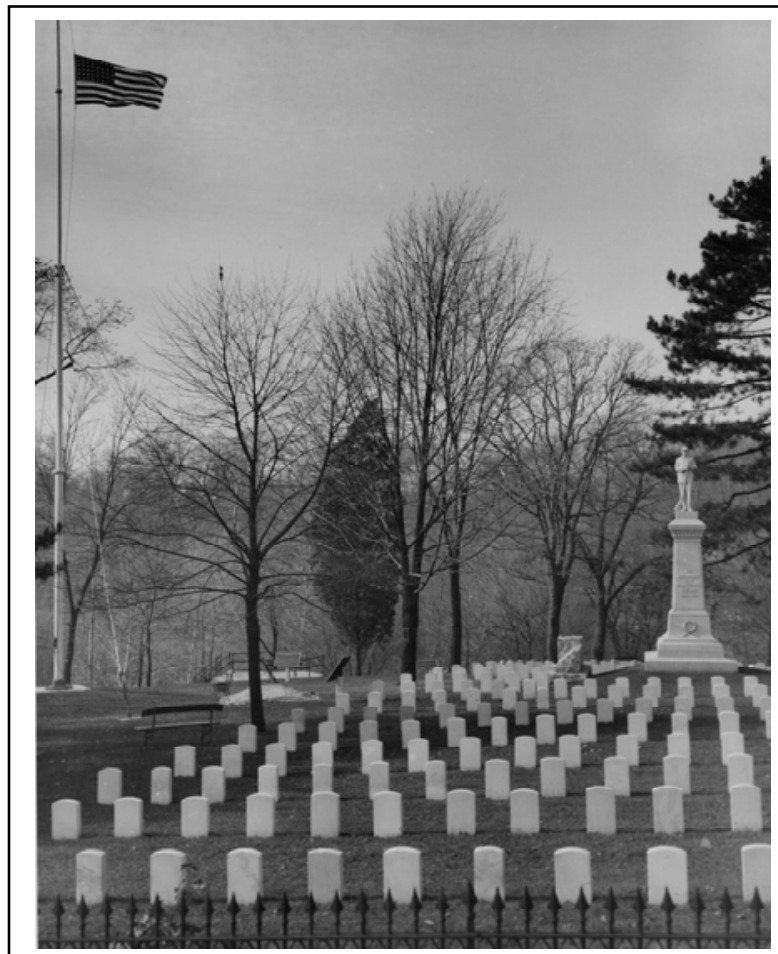

The Keokuk National Cemetery, ca. 1940. The cornerstone of the Estes House is to the left of the Unknown Soldier monument. From State Historical Society of Iowa, Des Moines.

local GAR post heeded the national GAR order to decorate the graves of deceased soldiers. The first program, which was spontaneous and unorganized, included a procession from Main Street to the National Cemetery; songs, speeches, and prayers at the cemetery; and the decoration of graves. The Keokuk GAR Decoration Day committee chairman used newspapers to ask for donations of flowers and money and to invite groups to participate in the procession by simply showing up on the morning of the parade. ${ }^{9}$

Despite the spontaneity of the celebration, the Keokuk Daily Gate City believed it to be a huge success. "Keokuk honored it-

9. Keokuk Daily Constitution (KDC), 5/30/1868. 
self," the paper declared, "in honoring so fitly and worthily . . . the Union soldiers who are buried in our cemetery." It further noted that despite the hasty arrangements, there was an unexpectedly large and enthusiastic crowd. It concluded that "a noticeable and worthy feature of [the procession] was the large attendance of soldiers, principally members of the Grand Army of the Republic," as well as students and their teachers, bands, and members of local social organizations. Keokuk's successful commemoration of the first Decoration Day, and Decoration Days in the late 1860s and the 1870s, placed it squarely within the mainstream of similar celebrations across former Union states. ${ }^{10}$

Another national theme that played out in Keokuk was the struggle between reconciliationist and anti-reconciliationist visions. In 1879 Rollin J. Wilson, a 25-year-old lawyer from Fairfield, delivered an anti-reconciliationist speech that marked Keokuk's most publicly controversial Decoration Day observance. Although Wilson was not a native or resident of Keokuk, the content and tone of his speech ignited a controversy between the city's two newspapers that highlighted divergent visions of the Civil War. Wilson delivered a long and wide-ranging address in which he excoriated Southerners for their treatment of African Americans and their belief in the Lost Cause ideology. He rooted his message in religion, claiming that the "God of Revelation ... teaches that war against wrong is right," the wrong being slavery and secession. Politically and historically, Confederates were "traitor[s] wearing the crown of the patriot." The victory of the colonies in the American Revolution and the Union in the Civil War had "dug a grave and in it buried those three repulsive ideas - that with the iron hand of tyranny had ruled too many generations - the divine right of kings, papal infallibility, [and] the inferiority of the races." Citing the differences between the Plymouth and Jamestown colonies, Wilson argued that the nation had been divided from its beginning. He emphasized that the split between North and South had only increased as the colonies, and then the United States, grew and prospered. ${ }^{11}$

10. KDC, 6/3/1868. For the nature of Decoration Day events in former Union states and the GAR's influence on the day, see Blight, Race and Reunion, 71; Silber, Romance of Reunion, 58-61; and Neff, Honoring the Civil War Dead, 136-41.

11. KDGC, 5/31/1879. 
Wilson's narrative of American history, emphasizing division, highlights what bothered him the most-reconciliation. Wilson was indignant that the hearts and minds of Southerners had not changed after the Civil War and that they were still trying to impose their political and social system on the North, despite the North's magnanimity during Reconstruction. He was thankful that "Iowa-the one state that is loyal yet-with a bright, broad distinction between patriotism and treason - [has] no confusion between the missions of the blue and the gray." He believed that reconciliation was a "squirmy, slimy, wart bearing sentimentalism" that dishonored the heroes who had defended the Union and the equality of men. In his conclusion, he emphasized that he would forgive Southerners, but only if they asked for forgiveness and changed their hearts and minds. Most important, forgiveness should not be granted at the expense of forgetting the Union dead. ${ }^{12}$

The Keokuk Daily Gate City, the Republican-leaning newspaper, called Wilson's speech "one of the most eloquent ever delivered in this city." The Keokuk Daily Constitution, the Democraticleaning newspaper, refused to print the speech, instead choosing to print the address from the previous year. The Constitution claimed that Wilson's speech was a dishonor to the dead and living and was a "great mistake. . . . For bitter partisan malignity and sectional spite ... it scarcely has a parallel in the lower order of noisy defamations." The next day, the Gate City criticized the Constitution for not running Wilson's speech, thereby preventing its readers from judging for themselves whether or not Wilson had given an appropriate address. The Gate City defended Wilson's speech and called it apolitical since he based his speech on the assumption that the purpose of the Civil War was to overthrow the great moral evils of slavery and secession. It was appropriate, then, that the living should resist the present

12. Ibid. Wilson's speech supports Neff's contention that there was widespread hostility to reconciliation and challenges Silber's claim (Romance of Reunion, 55) that reconciliation was widely accepted by the mid-1870s. Interestingly, Wilson's speech is very similar to a speech Blight cites (Race and Reunion, 95) from Stillwater, Minnesota, in 1879 in which the speaker opposed the "'false sentimentality' of reconciliation." Blight, however, cites the Stillwater speech as an example of an attitude that was present but much less common than reconciliation. 
racial inequality in the South against which Union soldiers had fought. The Gate City joined Wilson in criticizing Southerners for honoring the causes of states' rights and slavery rather than honoring the courage of their soldiers. Finally, the Gate City believed that Wilson's speech was appropriate because he "made an anti-state rights speech at an anti-state rights celebration." The controversy highlighted the strong emotions that commemoration of the dead could provoke. It demonstrated that some Northerners were unwilling to forgive Southerners, particularly when former Rebels clung to the Lost Cause ideology. ${ }^{13}$

Throughout the 1880s, anti-reconciliationist sentiments were more common in Keokuk than reconciliationist ones. Speakers at the National Cemetery in the early 1880s expressed hostility toward the South, though none reached the vitriol or caused the controversy that Wilson did. Speakers expressed outrage at the presence of former Confederates in Congress, the South's refusal to change, Confederate soldiers killing and maiming Iowans, and the willingness of some to justify the Lost Cause ideology. They also emphasized causes that Union soldiers had fought for, such as emancipation, preservation of the Union, and subverting foreign intrigues. In 1887 General James Tuttle, the state commander of the GAR who was from nearby Van Buren County, spoke at the Memorial Day event at the National Cemetery, urging the audience to defend the "character and integrity of the union soldier" against attacks by reconciliationist Northerners and rebels in the South. ${ }^{14}$

Most significantly, in the 1880s Keokuk's importance and the performance of Iowa soldiers in the war received frequent mention because they highlighted the local contribution to the war. In 1884 the Daily Gate City lamented that veterans from Keokuk

13. KDGC, 5/31/1879; KDC, 5/31/1879; KDGC, 6/1/1879.

14. KDGC, 6/3/1880, 5/31/1881, 5/31/1882, 5/31/1884, 5/31/1885, 5/31/1886, $5 / 31 / 1887$. The only speaker to express the reconciliationist theme in Keokuk was a Unitarian minister speaking to GAR members in his church. "We of the north," he noted, "and they of the south, have good reason to be proud of [our Civil War] memories. The skill, courage and loyalty on the one side was confronted by an equal fortitude and heroism on the other." In his conclusion, he urged GAR members to forgive their Southern brothers. KDC, 5/30/1881. This message of forgiveness was more likely to come from a minister speaking in a church than from a veteran speaking in a cemetery. 
such as the "brave Genl. S. R. Curtis, the chivalric Col. Worthington, the unflinching Col. Reid, the enthusiastic Col. Rankin, the true and loyal Major Perry, [and] the heroic Col. Abbott ... are with us no more." Writing about Tuttle's speech, the Gate City proudly pointed out that "it was here that the famous Iowa Second was organized. It proved to be a nursery of great soldiers. Gen. Samuel R. Curtis was colonel and when he was advanced Tuttle became colonel. So it fell to him to lead it at Donelson, where he and it became famous among soldiers." 15 The praise that the Gate City could heap on its native sons for their performance in the Civil War was something that their counterparts in Sioux City could not do.

KEOKUK AND SIOUX CITY were both Iowa river cities, but they occupied very different places geographically and within national Civil War narratives. Sioux City was founded in the 1850s on the Missouri River near the confluence of the Big Sioux and Floyd rivers. The city was oriented toward the West and originally served as a small steamboat port and wholesale center for traders, government officials, and military personnel going to the upper Missouri region to conduct business, diplomacy, and war with Indians. ${ }^{16}$

Throughout the Civil War, the population of Sioux City numbered about 1,000, but in 1868 the arrival of the Sioux City and Pacific Railroad linked the community to the Union Pacific line, and its population quickly quadrupled to about 4,000 by 1870 . Whereas railroads had stunted Keokuk's expansion, they led to increased growth in Sioux City. Three other railroads radiating to the north, east, and west were built in the early 1870s, providing the infrastructure for Sioux City's growth in the 1880s. Sioux City's population grew to 7,500 by 1880 and then increased dramatically to 38,000 by 1890.17

Land speculators, railroad entrepreneurs, steamboat merchants, and especially meatpackers and agricultural industrial-

15. KDGC, 5/31/1884, 5/31/1887.

16. Bill Silag, "Gateway to the Grasslands: Sioux City and the Missouri River Frontier," Western Historical Quarterly 14 (1983), 397-414.

17. Ibid., 412-13. 
ists fueled Sioux City's boom in the 1880s. A historian of Sioux City observed that "from the 1850s into the 1890s - the hegemony of the town boomers' entrepreneurial ideology was secure in Sioux City." Its economic niche as a supply center for the upper Missouri meant that it had a much more mobile population compared to other cities across the country. ${ }^{18}$ The new railroads tied Sioux City to the rest of the United States economically, but because of its location on the northwestern frontier and its unstable population base, it lacked firm cultural and historical links to the nation in its first decades. Thus, Civil War commemoration, though not the only nationalist cultural avenue pursued, gave Sioux City a way to access national culture. ${ }^{19}$ Sioux City, however, was based on economic growth, prosperity, and the future, so it was not until a sizable population of veterans settled in Sioux City that honoring the past became a part of the city's civic traditions.

Sioux City did not observe Decoration Day until 1884, sixteen years later than Keokuk's original recognition of the day. A Sioux City Journal editorial in 1880 praised the concept of Decoration Day but noted that "few of the towns up in this part of the northwest will observe the day-and Sioux City is among the number that will not - for the reason that soldier graves are few and far between." The tone of the 1880 editorial differed greatly from an editorial that appeared in 1883.

Sioux City was exceptional among the patriotic cities of its class in the northern states in paying no heed to Memorial Day. This neglect ought not to be. It does not matter that we have not the graves of soldiers here inviting decoration. We have, in common with our fellow-citizens everywhere, the sacred memory of their

18. Bill Silag, "A Mercantile History of Sioux City in the 1880s," Palimpsest 65 (1984), 26-32; idem, "Introduction: The Social Response to Industrialism in Sioux City," Annals of Iowa 50 (1989/1990), 119-29 (quote from p. 121); idem, "Citizens and Strangers: Geographic Mobility in the Sioux City Region," Great Plains Quarterly 2 (1982), 168-83.

19. Richard L. Poole, "Boosting Culture in the Gilded Age: Sioux City Theater, 1870-1904," Annals of Iowa 50 (1989/1990), 130-57, describes the growth of opera in Sioux City as the result of individual leadership, Sioux City's growth, and national cultural trends. Hewitt, "Blackface in the White Mind," documents white residents' appetite for minstrel shows that were also popular across the country. 
lives, and enjoy with others the incalculable blessings secured at the sacrifice of their death. ${ }^{20}$

To the editors of the Journal in 1883, celebrating Decoration Day was about celebrating the Union victory and Sioux City's growth rather than just memorializing the dead.

The reason the editorial perspective changed is that Sioux City's tremendous growth during the 1880s included Civil War veterans among the new settlers. By 1879, enough veterans were living in Sioux City to warrant the establishment of the B. F. Smith GAR Post No. 22. The original post only lasted about a year, but it was reestablished in 1884 with 95 members. The following year, a second post, the General Hancock Post No. 396, began with 33 members. The 1883 Journal editorial fretted that the community appeared ungrateful for these veterans who had recently moved to Sioux City and whose sacrifices in the Civil War had made the city's success possible. ${ }^{21}$

Readers of the Journal may have incorrectly assumed that Sioux City did not have a Civil War history since it was not mentioned in the 1880s editorials. ${ }^{22}$ Sioux City may not have had any direct connection to the battles between the Union and the Confederacy, but the Civil War did affect Sioux City. According to an early history of Woodbury County, "at the breaking out of the Rebellion, Sioux City was an outpost of civilization. . . . In place of going the front to battle with the slaveholders, her people had their hands full and their energies engaged at home, repressing the savage Sioux Indians." 23 At the beginning of the war, the U.S. army was small, and the majority of soldiers stationed in frontier forts, who had provided some shield against Indian attacks, were transferred to fight the Confederacy. After Sioux Indians murdered two local farmers in July 1861, the hastily organized Sioux City Frontier Guards provided protec-

20. SCJ, 5/29/1880, 5/31/1883.

21. Ibid. See also "History of Local G.A.R.," SCJ, 1905. The exact date of this article is unknown. It was accessed from the Sioux City Public Museum archives (GAR, SC 53, box 2). The two posts combined membership and names in 1892, becoming the General Hancock Post No. 22.

22. One mention of Sioux City during the Civil War to appear in a speech or the SCJ was an editorial, "Troubles at Home in '61," 6/11/1915.

23. History of Woodbury and Plymouth Counties (Chicago, 1890-1891), 166. 
tion throughout the rest of the summer but disbanded in October as winter approached and threats became less severe.

The area remained quiet until the Sioux uprisings in southwestern Minnesota in August 1862, in which more than 600 settlers were killed and thousands fled to northern Iowa. That prompted the state of Iowa to organize the Iowa Northern Border Brigade and the U.S. War Department to muster the Sixth and Seventh Iowa Volunteer Cavalry regiments. The Border Brigade built a string of posts stretching from Sioux City to the Iowa Great Lakes and stationed most of its cavalry in those two areas. The Sixth and Seventh Iowa Cavalry regiments operated more extensively and conducted raids against Indians in the Dakota Territory and Minnesota. The Border Brigade and Iowa Cavalry effectively ended any threat of Indian attacks in Sioux City and northwest Iowa through the remainder of the Civil War. ${ }^{24}$

Sioux City's experience during the Civil War was mostly an extension of the Indian Wars, and the heightened threat of attack was partly a result of the recall of troops to fight the Confederacy. Sioux City residents did not fight on the great battlefields; nor was it a place with hospitals for wounded soldiers or a cemetery for those who died. Although Sioux City did have a Civil War history, with dozens of residents who were part of the Sixth and Seventh Iowa Volunteer Cavalry regiments, the physical and psychological marks the war left on the community were minimal compared to the impact the war had on Keokuk. Thus, commemoration was not a part of Sioux City's civic culture in the 1870s and early 1880s.

The newly reformed B. F. Smith GAR Post No. 22 organized Sioux City's first observance of Decoration Day in 1884. The GAR Decoration Day committee adopted a program similar to Keokuk's. It included a procession of GAR members, bands, schoolchildren, and other organizations from downtown to Floyd Cemetery, where most of the deceased veterans were

24. See Marshall McKusick, The Iowa Northern Border Brigade (Iowa City, 1974); C. Addison Hickman, "Sioux City Frontier Guards," Palimpsest 23 (1942), 13644; Silag, "Gateway to the Grasslands," 405-6; Edith Wasson McElroy, The Undying Procession: Iowa's Civil War Regiments (Iowa Civil War Centennial Commission, 1964), 94-98; History of Woodbury and Plymouth Counties, 166-76. 
buried. ${ }^{25}$ The events at the cemetery, which also imitated programs in other cities, included prayers, speeches, and patriotic songs and concluded with the decoration of the graves. The Journal rated Sioux City's first Decoration Day as a rousing success because of the GAR's excellent preparation and citizens' enthusiastic participation. ${ }^{26}$

Speakers at Sioux City's Memorial Day events neglected local Civil War history, instead appropriating the Civil War narratives and themes used in the rest of the North. They lauded veterans' achievements at Fort Donelson, Shiloh, Vicksburg, Gettysburg, the March to the Sea, and Appomattox; extolled the virtues of Sherman, Grant, and Lincoln; praised emancipation and the Union; or mourned those who had fallen in the war. When they mentioned Sioux City, they stressed how Union soldiers' sacrifices and victory in the Civil War kept the West open to the economic growth and territorial expansion that made Sioux City's prosperity possible.

Sioux City's first Decoration Day address in 1884, delivered by Judge Joseph S. Lawrence, made clear how the Civil War was fought, in part, to secure the economic progress that Sioux City exemplified. According to Lawrence, who had recently moved to Sioux City from New York in 1881, those who had died in the Civil War and surviving veterans had "fought to prevent the destruction of free institutions, fought to prevent the interruption of our young and advancing civilization [and] died that they might bequeath to us and to our posterity the sacred and magnificent trusts which they themselves had received." He noted that Sioux City could continue to thrive "without prospect for civil war; with millions of acres yet unpopulated and with the heritage of the past to build upon." 27

In an 1891 Memorial Day address, Elbert H. Hubbard, a lawyer and Republican state senator who had moved to Sioux

25. Floyd Cemetery was named in honor of Sergeant Charles Floyd, who died near Sioux City while participating in the Lewis and Clark expedition, and is located in the northern part of Sioux City. It is distinct from the Sergeant Floyd monument and burial site, which is located about three miles to the south.

26. SCJ, 5/30/1884, 5/31/1884.

27. SCJ, 5/31/1884. Lawrence also spoke at Sioux City Memorial Day observances in 1900 and 1905. 
City in 1874, claimed that "because of that war we see before us a peace and prosperity beyond the horizon of our thought." The Civil War secured "this vast and fertile land, infinitely diversified in climate and production ... with the iron bonds of the pathway of commerce." 28

The Sioux City Journal also emphasized the themes of expansion and prosperity. An 1885 editorial stated that the Union victory kept the West open to settlement. It was thankful that hundreds of thousands had given their lives because "there are some things worse than war. That this nation should be broken into fragments and the great movement of humanity on this new continent to its highest possibilities balked almost before it was fairly begun, was a more unspeakable calamity even than war." Another editorial in 1889 suggested an even stronger connection between the growth of the United States, Union victory, and soldiers' sacrifice. To the editors, the value of Civil War soldiers' service would not be known until "this continent is peopled to its utmost limit, not till there shall be between the oceans the hundreds of millions whom the resources of this land are fully able to support, not till the fullness of destiny has been wrought out in that direction can be truly known the real service which was done by those who offered their lives to save the nation." 29

Although Sioux City did not play a significant role in the Civil War, its boom during the 1880s was its way of doing its part to achieve the goals of the Civil War. Memorial Day provided an annual opportunity for Sioux City boosters to link their city's development to the Civil War. Even more fitting occasions for Sioux City to show that it had played an important role in the Civil War because of its subsequent economic growth were state GAR encampments held in the city.

THE TIE between Sioux City's vitality and its commemoration of the Civil War is evident in the city's and local GAR posts' hosting of the GAR Department of Iowa's Twelfth Annual Encampment in 1886. According to the Journal, Sioux City was an

28. $S C J, 5 / 31 / 1891$.

29. SCJ, $5 / 30 / 1889$. 
ideal choice to host the encampment because "no other body of men could be more welcome in this metropolis of northwestern Iowa, that section of the state which more than any other in the state has been settled and developed, and is now inhabited, by surviving veterans of the war." Moreover, since members of the GAR represented the "respectability, the thrift, the progress, the wealth, and the prosperity of the state . . . it was every way fit that Sioux City, itself an example of thrift and progress, should be chosen as the meeting place." The Journal, in a lengthy editorial, detailed Sioux City's remarkable growth. It predicted that veterans from across the state would return home with a favorable impression of Sioux City's rapid growth, for "within the brief space of fifteen or twenty years the distribution of Iowa's population has been utterly revolutionized by the march of settlement towards the west, and especially toward the northwest." 30

Captain J. S. Lothrop, an officer in the B. F. Smith Post No. 22 who had moved to Sioux City in 1884, gave the welcome speech. His description of Sioux City highlighted progress. He observed that the leaders of Sioux City could not welcome GAR members to "rolling palaces ... pavement ... graveled walks in flower-bedecked and wide-extended parks . . . or massive halls." Instead, he urged visitors to remember, "when you look upon our muddy and unpaved streets; when you note the incompleteness of our public houses; when you observe the unfinished appearance of things that everywhere meet the eye, . . . that but yesterday a village, today a city." 31

The next speaker, Judge Advocate Josiah Given of the state GAR, acknowledged the growth of Sioux City and its western character when he "recall[ed] one year ago when our encampment was held on the banks of the Mississippi, that Sioux City signified that it awaited our coming. There were voices who spoke of how in the closing days of the war many of the old soldiers drifted out onto these prairies, and we met and decided to go to that gem city of western Iowa - the city of the Sioux." These commentators made it clear that Sioux City was hosting

30. SCJ, 4/7/1886, 4/8/1886.

31. SCJ, 4/8/1886. 
the GAR encampment not because of its role in the Civil War but because it had grown tremendously after the Civil War and had given veterans the opportunity to pursue prosperity. ${ }^{32}$

In stark contrast, when Keokuk hosted the nineteenth Iowa GAR encampment in 1893, its role in the Civil War was a common theme. Some speakers recalled their passage through Keokuk on the way to war. On the first night of the event, one of the speakers at the campfire noted that "it was through Keokuk [that] so many thousands of Iowa boys went down to the war. It was here that their state faded upon their vision as they went away, and here so many tearful good-byes were said." Captain T. M. Fee of Centerville, the next speaker on the roster, remembered that "during the bitter progress of the war we never forgot the kindness and hospitality shown us by the citizens of Keokuk." 33

Others hailed Keokuk as the home of great Civil War officers and statesmen. Ed S. Carter, who chaired the Keokuk encampment committee, opened the ceremonies at the First Baptist Church by noting that "there was no other city in the state of Iowa that was menaced as Keokuk was during the Civil War on account of her position being so near the boundary line of the two factions, yet the soldiers came and marched on to victory. ... In the name of the immortal Curtis, Belknap, Torrence and those brave soldiers of Keokuk whose lives were sacrificed on the field of battle, I welcome you." 34 On the last night of the encampment, Carter delivered a eulogy to the late William Belknap, who had moved to Keokuk in 1851 and later became a Civil War general and President Grant's secretary of war. Carter claimed that "it was the confidence and encouragement of the people of Keokuk that moved him to do what he had done." 35

Weaving the two themes together was Judge John N. Irwin, who noted how "fitting it is that the Grand Army of the Republic should meet in Keokuk, whence most of the Iowa soldiers went to the war and to which fewer of them returned." He con-

32. Ibid.

33. Keokuk Daily Constitution-Democrat (KDC-D), 4/26/1893.

34. Ibid.

35. KDC-D, 4/27/1893. 
tinued, lauding Keokuk as "the home of Curtis, Torrence, Hillis, Parrott, and last but not least, the imperial Belknap." 36 References to mustering in Keokuk and the city's heroes were only a part of each speech, but these themes gave speakers a way to praise the host city besides the perfunctory gratitude for hospitality. They linked Keokuk clearly with its Civil War past and showed that it had played an important role in the Civil War.

In 1898 Sioux City hosted the twenty-fourth Department of Iowa GAR state encampment. Like the 1886 state encampment the city had hosted, it provided an opportunity to show off its prosperity. This time, instead of economic growth, Sioux City wanted to demonstrate recovery from the Panic of 1893, which had hit Sioux City especially hard. ${ }^{37}$ During the state encampment at Keokuk in 1893, both Keokuk papers had mocked Sioux City's financial plight after a major bank collapsed. A Gate City editorial commented that the "Sioux City way' appears to be a very bad way," and the Constitution-Democrat noted that "it will be a long time before Sioux City recovers from the present crash. It is the same old story of too much boom on too little bottom" a story Keokuk knew only too well. ${ }^{38}$ And, of course, Keokuk's papers failed to acknowledge that Sioux City had by that time surpassed Keokuk in population and prosperity.

Whether aware of the comments in Keokuk papers from five years before or not, Sioux City GAR members, city officials, and the Journal made significant efforts to give visitors a warm welcome and a comfortable experience. ${ }^{39}$ Unfortunately, attendance was poor because the state GAR office publicized the encampment dates as June 16-17 instead of June 14-16. The poor attendance was a great disappointment because of all the preparations that had been made to show off Sioux City's progress. Sioux City's efforts did not go unnoticed; several official GAR resolutions and unofficial testimonies of attendees thanked Sioux City for its hospitality and proclaimed that "the city has

36. Ibid.

37. Silag, "Introduction," 122-23.

38. KDGC, 4/28/1893.

39. SCJ, 6/13/1898, 6/14/1898. 
more than redeemed every pledge made, and that they have been carried out in the traditional 'Sioux City way.' " 40

The Journal hoped that when visiting GAR members arrived in Sioux City in 1898, they would "look about and see evidences of prosperity, of peace and of promise and then we want to assure them that we are only paying part of a debt in doing them honor." 41 Unlike the 1886 encampment, however, that was the only mention of the prosperity theme that had been so dominant in the past. Although speakers still did not cite examples of Sioux City's role in the Civil War, by 1898 they could praise some of its citizens who had moved there. For example, the Journal extolled the war and postwar accomplishments of Madison B. Davis, who had moved to Sioux City in 1875 and was running for the state GAR commander post. ${ }^{42}$ When the Journal ran an article of "War Stories Told By Veterans," it included one from J. S. Lothrop, who had moved to Sioux City from Illinois in 1884. ${ }^{43}$ Although Sioux City had a few residents to honor, the fact that they were from somewhere else when they became Civil War heroes made Sioux City different than Keokuk. Keokuk's role during the Civil War was to produce soldiers, nurse them back to health, or provide a final resting place, while Sioux City was a place in which surviving veterans could thrive.

Besides the themes of Sioux City's hospitality, its current residents who served in the war, and the usual GAR business, reconciliation was a major theme at the 1898 encampment. One of several speakers at the YMCA campfire protested "the proposition that patriotic action now on the part of ex-confederates wipes out the fact that they once were traitors." 44 The next orator, however, promoted reconciliation, believing that "the people of the north should forget that there ever has been a division of the nation." Governor Leslie Shaw, who spoke at several campfires and churches during the encampment, also advocated reconciliation. He told a story about Iowa troops in the Spanish-

40. SCJ, 6/16/1898, 6/17/1898.

41. SCJ, 6/14/1898.

42. Ibid.

43. SCJ, 6/15/1898.

44. Ibid. 
American War who were training in the South. The Iowans came across a Confederate monument and removed their hats in honor, which greatly pleased the Southern crowd. To Shaw, those Iowans proved that "there was no more north, south, east or west." In another address, he opined that the current SpanishAmerican War created Americans and wiped out sectional divisions. Governor Shaw's comments were representative of reconciliationist sentiments that had become prominent throughout the country. ${ }^{45}$

THE RECONCILIATIONIST MOOD present in the rest of the nation was evident in Sioux City and Keokuk. An 1885 Memorial Day speaker in Sioux City told the crowd that "while we scatter flowers on the graves of the blue, we will not forget to drop a flower on the graves of the grey." At the 1887 and 1888 Memorial Day services, speakers urged the crowd to remember the sacrifice and heroism of both Union and Confederate troops and the virtues of forgiveness and brotherhood. In 1895 a speaker noted that "time ameliorates and softens; and it is well that it is so. The bitterness of the conflict has passed away." A speaker in Keokuk reminded listeners that Southern veterans, like GAR members, also mourned their fallen comrades. Northerners should not "slander the southern soldier nor place upon his name the brand of traitor." Although the Civil War was a "bitter memory," it was important to forgive the Southern soldiers who returned to destroyed homes. The goal of the Civil War was to preserve the Union, which included the South. ${ }^{46}$

Despite the reconciliationist sentiments, others in Keokuk, Sioux City, and across Iowa were not as willing to forgive the South. At the 1885 Memorial Day ceremony in Sioux City, the crowd "joined in singing 'John Brown.' The 'Fighting Parson' caught the old enthusiasm, and when he led in the second stanza, 'We'll Hang Jeff Davis on a Sour Apple Tree,' the audience joined in a way that threatened to raise the roof and the meeting broke

45. SCJ, 6/16/1898.

46. SCJ, 5/31/1885, 5/31/1887, 5/31/1888, 5/31/1895; KDC-D, 5/30/1893; see also $K D C-D, 5 / 31 / 1895$. 
up amid rousing cheers." 47 Like other GAR members across the country, many Iowa GAR members believed that reconciliation with the South was incompatible with the principles of GAR. 48 The 1886 GAR state encampment passed two resolutions that opposed honoring recently deceased ex-Confederate and U.S. Secretary of the Interior Jacob Thompson and Jefferson Davis because the GAR considered each a traitor. A resolution to donate $\$ 100$ to the National Confederate Soldiers' Home out of brotherhood was tabled because many officers believed it would cause too many members to withdraw from the GAR. ${ }^{49}$ The coexistence of reconciliationist and anti-reconciliationist themes demonstrates that even as Sioux City and Keokuk drew on different narratives when commemorating the Civil War, both accessed themes of Civil War memory that were present in the rest of the country.

THE PURPOSE of Memorial Day and GAR encampments was to honor the dead and surviving veterans. At the turn of the century, those interested in the Civil War also turned to monument building in order to preserve the message of the war and the memory of the dead for future generations. Across the United States, communities erected Civil War monuments "to mold history into its rightful pattern" and "to mold a landscape of collective memory." 50 The physical nature, location, and subject of the monuments built in Keokuk and Sioux City demonstrated what town fathers in each city considered important about their

47. SCJ, 5/31/1885.

48. McConnell, Glorious Contentment, 190-93.

49. Charles Thurman Mindling, "The Grand Army of the Republic in Iowa Politics and Society" (M.A. thesis, State University of Iowa, 1949), 76-77.

50. Kirk Savage, Standing Soldiers, Kneeling Slaves: Race, War, and Monument in Nineteenth-Century America (Princeton, NJ, 1997), 4. In general, Savage discusses the importance of monuments in shaping the memory and public perception of former slaves and Union soldiers. See also Mayo, War Memorials as Political Landscape, who discusses the importance of monuments in shaping memory and public perception of U.S. wars. He specifically discusses the Civil War on pp. 171-79 and 217-21. For other examples of the role of monuments in shaping memory, see Neff, Honoring the Civil War Dead, 1-3; and Piehler, Remembering War, 54-55. 
history. ${ }^{51}$ Keokuk erected a monument to Brigadier General Samuel R. Curtis that reflected the significance of the Civil War in their community's history. In Sioux City, the grandeur of the Sergeant Floyd monument compared to the GAR monument in the Floyd Cemetery demonstrates how the city privileged westward expansion over the Civil War in its history and memory. ${ }^{52}$

On July 4, 1898, Keokuk dedicated an equestrian statue of Curtis, the commanding officer of the Union victory at Pea Ridge in 1862. After serving in the Mexican War, Curtis settled in Keokuk and was elected mayor and U.S. representative in the 1850s. He resigned from Congress at the outbreak of the Civil War to raise a regiment in Iowa. The speakers at the monument's dedication focused on General Curtis's and Keokuk's contribution to the war. The first speaker, C. P. Birge of Keokuk, recalled being in Keokuk, hearing the news of Fort Sumter, "the thrill with which this condition reached us, when we realized what it all meant," and the eagerness and resolve of the residents. The majority of his speech consisted of listing veterans still residing in Keokuk so they could receive proper recognition. Later in the day, just up the river at Rand Park, Colonel C. M. Stanton of Centerville, who had served under Curtis, said that "no other city in Iowa has such a grand war record as Keokuk," so the "statue stands not only [as] a memorial of General Curtis but it is also the tribute of a generous people [and] the fifteen companies which went from Keokuk to the civil war." 53

51. According to Neff, Honoring the Civil War Dead, 3, monuments tell us more about those who plan, design, and build monuments than about those who are being honored.

52. Monument construction in Sioux City and Keokuk around the turn of the century is consistent with patterns in the state of Iowa. For examples of monuments specific to Iowa, whether inside or outside the state, see Lowe, "'A Grand and Patriotic Pilgrimage.'” Timothy B. Smith, "David Wilson Reed: Father of Shiloh National Military Park," Annals of Iowa 62 (2003), and idem, "The Politics of Battlefield Preservation: David B. Henderson and the National Military Parks," Annals of Iowa 66 (2007), describes the importance of Iowans in the development of national military parks in the early twentieth century. See also Alonzo Abernethy, Dedication of Monuments Erected by the State of Iowa: Commemorating the Death, Suffering, and Valor of Her Soldiers on the Battlefields of Vicksburg, Lookout Mountain, Missionary Ridge, Shiloh, and in the Confederate Prison at Andersonville (Des Moines, 1908). For a brief survey of monument building in the North, see McConnell, Glorious Contentment, 188.

53. KDGC, 7/4/1898. 


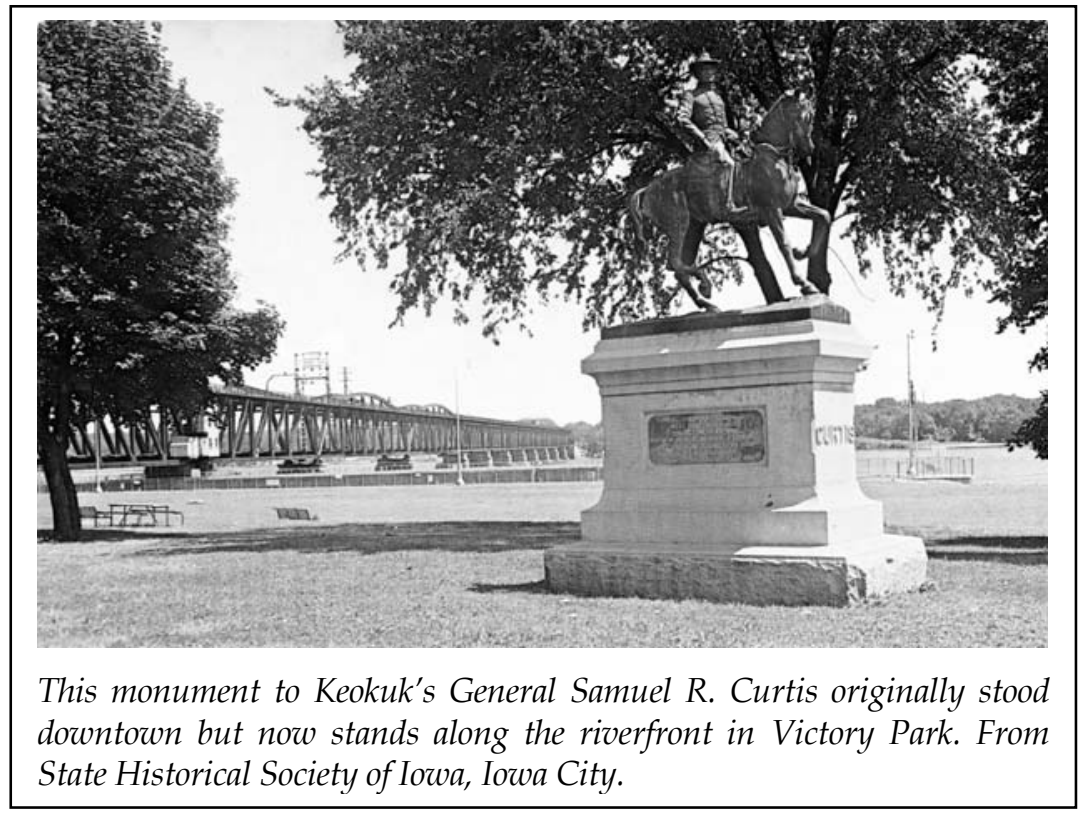

Although the dedication occurred on Independence Day during the Spanish-American War, memory of the Civil War prevailed among those at the ceremonies. The General Curtis monument reminded residents of the Civil War in a different way than the National Cemetery and the Estes House, Keokuk's other markers of its Civil War history, which were reminders of death, injury, and sacrifice. The General Curtis statue was a symbol of Keokuk's success and importance in the Civil War. The planners placed the monument on Main Street, where General Curtis's likeness would serve as a reminder for future generations of Keokuk's achievements during the Civil War. ${ }^{54}$

While Keokuk honored one of its own, Sioux City built a monument to Sergeant Charles Floyd, whose intention was to pass through the area but died at the place where the city was eventually founded. ${ }^{55}$ The Lewis and Clark expedition, of which

54. KDGC, 7/5/1898.

55. According to Mayo, War Memorials as Political Landscape, 117-18, 166-67, Civil War monuments are much more common than those dedicated to Manifest Destiny. Although Mayo focuses specifically on monuments dedicated to 
he was a part, represented the ideals of growth and prosperity that Sioux City believed it exemplified. Unlike Keokuk, Sioux City could not boast of the achievement of one of its residents in the Civil War, but the Sergeant Floyd monument was a physical reminder, visible to all, that Sioux City had an important role in American history. The designer of the monument, Captain Hiram M. Chittendon of the U.S. Army Corps of Engineers, wanted the monument to be "imposing in appearance, and visible at a great distance, dominating the entire valley in its vicinity." 56

Floyd was the only member of the Lewis and Clark expedition to die, succumbing to appendicitis near the future site of Sioux City, where he was buried. In 1857 some of Sioux City's early settlers saved his remains from the "incessant, irresistible, and irreverent currents of the Missouri," reburied him on a bluff overlooking the village, and proposed that a monument be built to preserve his place in American history. According to the Journal, the Civil War and the postwar "fight to make Sioux City a metropolis" had distracted citizens from financing and constructing a proper monument. ${ }^{57}$ In the 1890 s, however, several events converged to make the monument a reality. Reuben G. Thwaites, the director of the Wisconsin Historical Society, discovered Floyd's journal in the archives in Madison, which led to a new curiosity about Floyd among some historians and citizens of Sioux City. The interest in Floyd corresponded to a renewed attention across the country to the Lewis and Clark expedition as its centennial approached. In Sioux City in 1895, concerned citizens rediscovered Floyd's remains, after the 1857 reburial site was lost, and organized the Floyd Memorial Association to acquire funds to properly mark his grave and build a monument. ${ }^{58}$

The Sergeant Charles Floyd Monument, a 100-foot-high sandstone obelisk, was dedicated on Memorial Day in 1901. The

earlier wars, the Floyd monument fits his description of Manifest Destiny monuments. In particular, he argues that in these monuments, "individual battles and heroes are often commemorated more than the fact that a war was won" (118).

56. Quoted in James J. Holmberg, "Monument to a 'Young Man of Much Merit,'” We Proceeded On 22 (Aug. 1996), 8.

57. SCJ, 5/30/1901.

58. Ibid. 


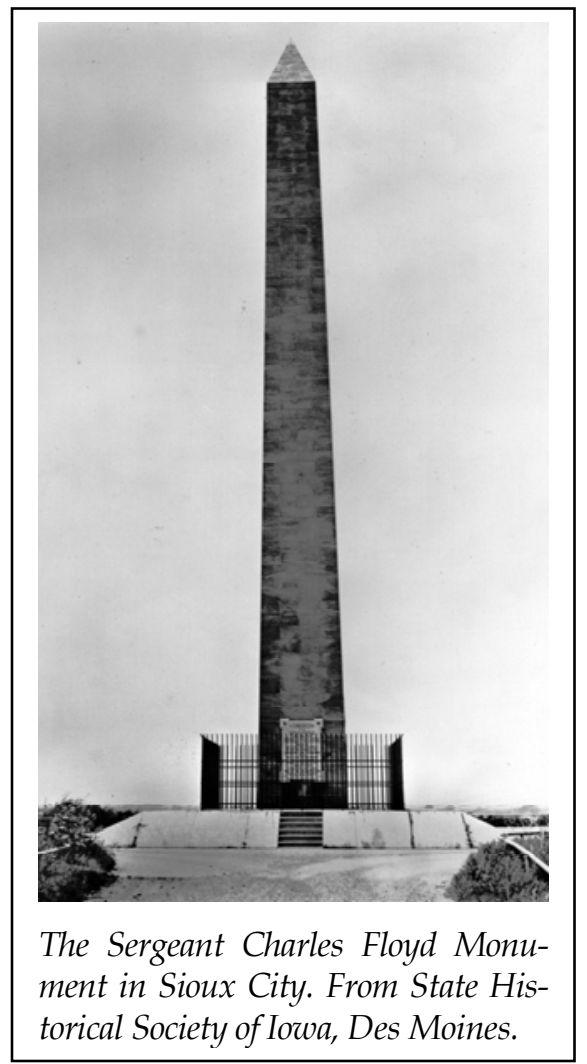

selection of Memorial Day, a day devoted to the Civil War dead, as the occasion to dedicate the monument shows how the memory of westward expansion coalesced with that of the Civil War. The space the Journal devoted to the ceremonies far exceeded the space it gave to any prior or subsequent Memorial Day observances, indicating the importance of the Floyd monument to Sioux City. The Memorial Day edition included articles about the arrival of dignitaries and speakers, a biography of Sergeant Floyd, a history of his grave and monument in Sioux City, a history of the Louisiana Purchase, and a poem about the Floyd monument. The Journal described in great detail the ceremonies and speeches at the monument, the memorial exercises at Floyd Cemetery, where the GAR honored the Civil War dead, the participants in the parade, the program at the opera house, and the evening's events at the courthouse, where speakers discussed the contents of Floyd's journals and the meaning of the monument. Civil War commemoration was clearly secondary to the celebration of the Floyd monument, even though the GAR played an important role in the days' events. GAR members performed the dedication rituals to their "fellow soldier," had prominent seats at the dedication, and conducted their "memorial service to the dead" at the opera house immediately before the keynote address. However, "all the exercises of the day had for their theme the monument"; the highlight of a normal Memorial Day, the decoration of the graves, was relegated to a less 


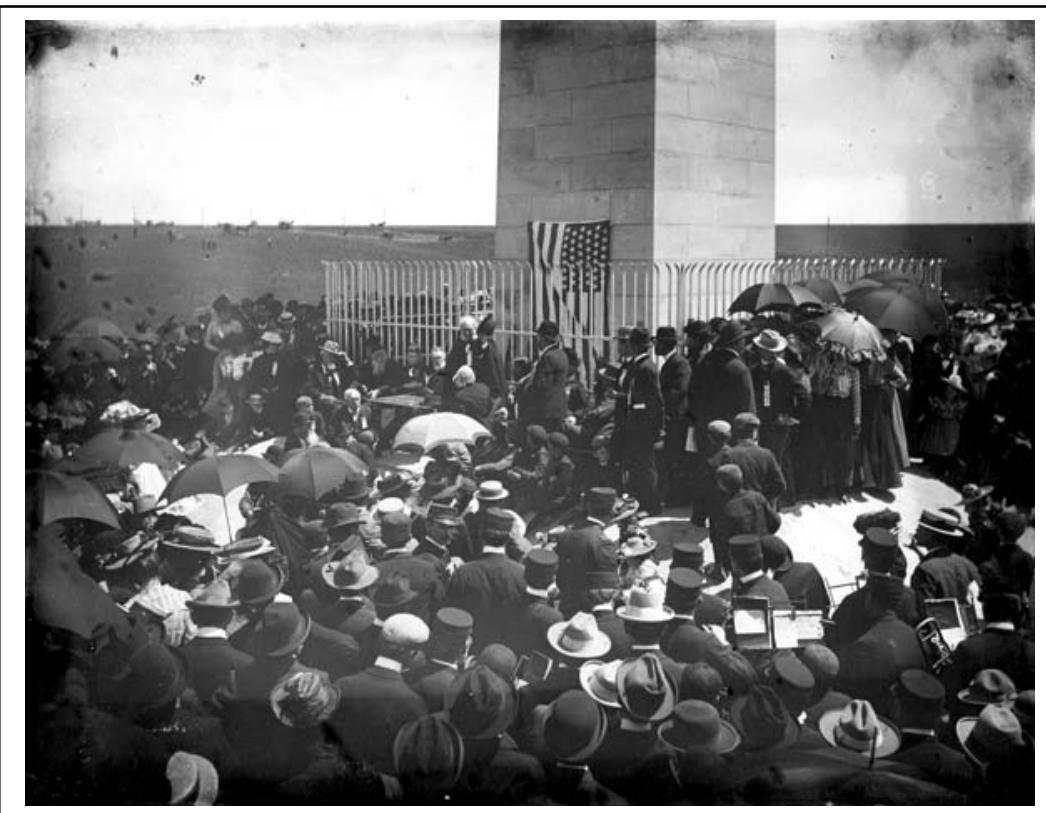

Residents gather on Memorial Day in 1901 to dedicate the Floyd monument. Photo courtesy of the Sioux City Public Museum.

important occasion occurring early in the morning before the dedication of the Floyd monument. ${ }^{59}$

The day's speakers focused on Floyd, the monument, and westward expansion. John A. Kasson, a U.S. diplomat originally from Iowa, titled his speech "The Expansion of the Republic." He compared explorers, such as Floyd, Lewis, and Clark, to veterans of the American Revolution, the Barbary Wars, the War of 1812, the Civil War, and the Spanish-American War. Their courage and endurance expanded the territorial and ideological scope of the United States in North America, the Caribbean, and the Pacific. Placing Sioux City in the Mississippi Valley, Kasson declared that "this incomparable valley, dowered with inexhaustible wealth ... was destined to become the scene of the greatest conflict in the history of the American continent." He claimed that the "great hearted men of the upper valley

59. The SCJ devoted three full pages to the celebration on May 30, 1901, and nearly as much the next day. 
clothed themselves in the panoply of the Union. . . . They did not die in vain. ... All hail to the memory of these heroes dead; and all hail to their comrades who live to salute the dawn of this day dedicated to the memory of their deeds." 60

In other ceremonies later that evening, Dr. S. P. Yeomans, a prominent member of the Sioux City community, envisioned the Floyd monument as a representation of American ideals, including the courage and endurance of the Lewis and Clark expedition and the American people, the territorial and population growth of the United States, the victory of civilization over barbarism, and the victory of liberty over slavery in the Civil War. In his narrative, too, the Civil War ensured a free and peaceful westward expansion that enabled cities like Sioux City to achieve "a career of prosperity and progress unparalleled in the history of this or any other nation." 61

Three years later in Sioux City, on Memorial Day in 1904, the members of General Hancock Post No. 22 dedicated a more humble monument to their fallen comrades. Instead of a highly visible monument on a bluff overlooking the city, the GAR monument was built in a cemetery on the city's northeast side and consists of a three-foot-high base with a ten-foot red granite shaft. The text of the monument included statements about "an undying love for comrades of the war" and the ideals of victory, purity, and humility. ${ }^{62}$ At the ceremonies, Judge Albert Wakefield, who was born in Sioux City in 1875, saluted the GAR for its "patriotic devotion to the memory of our dead." The monument was "cut out of enduring granite and inscribed to express your love and admiration." Captain J. S. Lothrop noted that "this stone is sacred to the memory of all old soldiers, sailors and marines who are dead. It is sacred to the old soldiers who are gathered about me here today." He acknowledged that the

60. SCJ, 5/31/1901.

61. SCJ, 5/31/1901.

62. The full text of the monument reads: "We present a wreath, a tribute to the memory of our dead and a symbol of an undying love for comrades of the war. As a last token of affection from comrades in arms, our dead are crowned with laurel-symbol of victory. As a symbol of purity we offer at each lowly grave a rose. May future generations emulate the unselfish devotion of even the lowliest of our heroes." 
monument was for the living, but it paled in comparison to the "towering temple of the American republic" that Civil War soldiers had built. ${ }^{63}$ The monument was not necessarily meant to be a public reminder of the participation of some of Sioux City's members in the Civil War; instead, it was a salute to the deceased by their living comrades who wanted to make sure they would remain properly honored. Its location, in the middle of a cemetery on the outskirts of town, represented the periphery of the Civil War in Sioux City memory. The Sergeant Floyd monument's location on a high bluff, with a sweeping vista of the Missouri River and the western horizon, symbolized Sioux City citizens' belief in their community's importance in the westward expansion of the United States.

FROM THE TURN OF THE CENTURY to World War I, the link between Sioux City's prosperity and the Civil War appeared much less frequently at Memorial Day events, but the few references to that narrative demonstrate the unique way Sioux City remembered the Civil War. A Journal editorial in 1904 claimed that the Civil War "opened the way to opportunity. It cleared the way. It capitalized the nation. Eighty millions of people are the beneficiaries of what they did." Rev. Manley B. Townsend, the First Unitarian Church minister speaking in 1910, believed that "forty-five years after the close of that war finds us at profound peace within our borders and with all the world. Our population has doubled. Our prestige has enormously increased. We have grown great and strong and rich." In 1914 County Attorney C. M. Jepson told the ever-declining number of surviving veterans that they "have seen their efforts rewarded. They have seen the country grow and expand. They have seen development along all lines. They have seen the spirit of which they were the embodiment." 64

Speaking at Keokuk's Memorial Day ceremony in 1914, James B. Weaver, son of the former Civil War general and presidential candidate, appropriately synthesized the most important themes in Civil War commemoration in Keokuk since the incep-

63. SCJ, 5/31/1904.

64. SCJ, 5/30/1904, 5/31/1910, 5/31/1914. 
tion of Memorial Day. He discussed the greatness and sacredness of Memorial Day and the need to continue to honor the dead. He positioned the Civil War in the context of great ancient and American battles, but he also praised Keokuk's role in the Civil War. Keokuk was where his "father and his comrades of the Second Iowa gathered and took the oath of service to the nation. Here they and their comrades drilled and practiced the first lessons in the hard life just ahead of them." On Keokuk's "streets still stand buildings whose walls sent back the echo of their marching feet and it was the friendly streets of your city that many of them carried away in their hearts as the last glimpse of home." To Weaver, Keokuk did its part in the Civil War and was "indeed sacred ground, hallowed by tender memories and forever linked with the state's first sacrifice for the life of the nation." 65 Weaver's speech in 1914 provided a review of the dominant themes of Civil War memory and the importance of Keokuk, but after World War I began, the memory of the Civil War came to occupy a less important place in both cities' civic culture.

The 1915 state GAR encampment in Sioux City was a preview of the decline of Civil War memory brought on by World War I. The Journal's editors, in contrast to the GAR participants, emphasized Civil War memory and the GAR. In one editorial, the Journal focused on the GAR and its distinction as a "typically American organization" because of its open membership to all veterans of the Civil War and because "all are put on a common level as comrades." Unfortunately, the passage of time was devouring the rolls, and the "annual encampments have lost a little of their old time activity, perhaps, but there is no diminution in patriotism and ardor." 66 The Journal also discovered that Sioux City had a Civil War history and provided a brief summary of the Sioux City Frontier Guards, Iowa Northern Border Brigade, and Iowa Cavalry regiments. ${ }^{67}$

65. KDGC, 5/31/1914.

66. SCJ, 6/8/1915. The Journal was not talking about race, but Barbara Gannon, The Won Cause: Black and White Comradeship in the Grand Army of the Republic (Chapel Hill, NC, 2011), 5, argues that within the GAR "most white veterans accepted black Americans."

67. SCJ, 6/11/1915. 


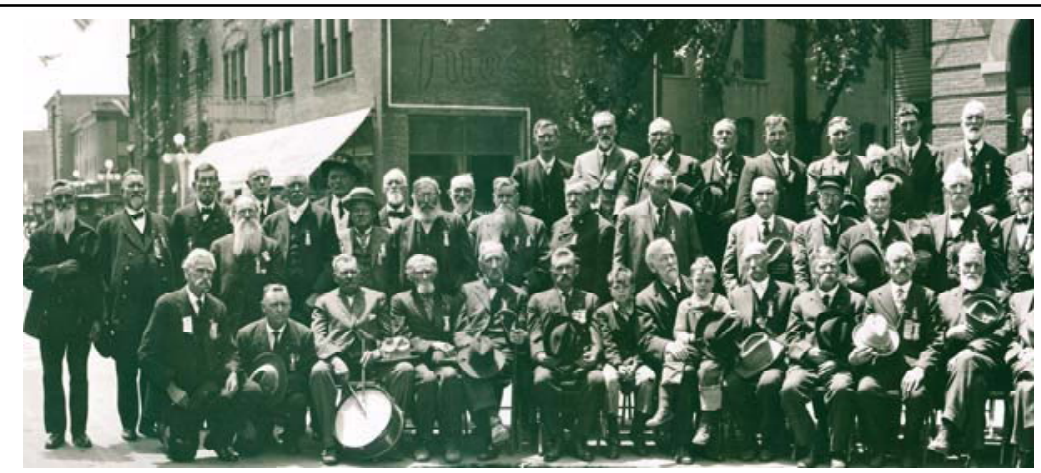

This is a segment of a panoramic photo of veterans attending the 41st Grand Army of the Republic state encampment in Sioux City in 1915. From State Historical Society of Iowa, Des Moines.

Most of the resolutions and speakers at the encampment, however, focused more on the war raging in Europe. The GAR passed resolutions that included support for neutrality, condemnation of the sinking of the Lusitania and all U-boat attacks, criticism of the chaos in Mexico, and support for President Wilson's handling of these issues. Resolutions generally opposed war, and speakers also reflected that attitude. One speaker expressed his disappointment with the resignation of William Jennings Bryan as secretary of state because he believed it was a "blow to peace." Col. David J. Palmer, the GAR national commander, who was from Iowa, disagreed; he approved of Bryan's resignation because his replacement, Robert Lansing, would get the United States better prepared for war. Palmer did not want the United States involved in the war, but realized that it might be drawn into the conflict and it was best to be prepared. ${ }^{68}$ The GAR's focus on World War I demonstrated how the size and scope of World War I, combined with the ever-shrinking ranks of Civil War veterans, dislodged the Civil War from its revered place in citizens' and veterans' memory.

World War I marked a shift in Civil War commemoration in both Keokuk and Sioux City. There were still processions, decorations, and ceremonies at the cemeteries, but GAR members 
now shared the stage with World War I veterans. Most notably, speakers in both cities discussed contemporary national and international issues rather than the Civil War. During World War I, speakers emphasized the American tradition of fighting for liberty and democracy or the horrible nature of the Germans. ${ }^{69}$ In the first few years after the war, a major concern for speakers was the rise of Bolshevism in the United States and around the world. ${ }^{70}$ Speakers in the 1920s and 1930s often gave their opinions of America's role in the world. Some believed that the United States should lead the world by spreading peace and democracy. ${ }^{71}$ Isolationists in both cities, in contrast, used Memorial Day to express their desire to stay completely out of world affairs. ${ }^{72}$ In some cases, a speaker wove the Civil War or the GAR into his narrative, but it was never a focal point. A speaker in Sioux City in 1927 lamented that "the mad race for the elusive dollar is causing many Americans to lose sight of their civic responsibilities" such as honoring Memorial Day. His concern, however, went unheard. As the Civil War became more distant and veterans died off, the Civil War came to share Memorial Day with other wars and contemporary issues. ${ }^{73}$

Although Memorial Day speeches in Keokuk and Sioux City became indistinguishable after World War I because of their deemphasis of the Civil War, the last state GAR encampment each city hosted still highlighted the differences between their Civil War memories. When Keokuk hosted the fifty-second encampment in 1926, it was an opportunity for visiting GAR members and residents of Keokuk to review the city's role in the Civil War. The Gate City noted that Keokuk was home to "Iowa's only national cemetery," "the point of embarkation

69. Keokuk Daily Gate City and Constitution-Democrat (KDGC-C-D), 5/31/1917, 5/31/1918, 5/31/1919; SCJ, 5/31/1916, 5/31/1918.

70. KDGC-C-D, 5/31/1920.

71. KDGC-C-D, 5/31/1921, 5/31/1923, 5/30/1925; KDGC, 5/31/1933; SCJ, 5/31/1925, 5/31/1929, 5/31/1933, 5/31/1938.

72. SCJ, 5/31/1935. See also a SCJ political cartoon, "A Tribute to the Dead, and a Responsibility to the Living," 5/30/1938. In the cartoon, a solemn-looking Uncle Sam holds a placard stating, "A firm determination to stay out of Europe's wars" while standing over the grave of a soldier killed in 1918.

73. Quote is from SCJ,5/31/1927. For other examples of speakers concerned with declining civic participation, see KDGC-C-D, 5/31/1922. 
to the south of every Iowa regiment but one," "the home of five generals," and the location of "the fine equestrian statue of Gen. Samuel Ryan Curtis [and] the old Estes House." The Gate City included articles about Civil War points of interest in town, a brief history of the 1893 encampment in Keokuk, and a biography of Colonel William Torrence, the namesake of one of Keokuk's GAR posts. Although the GAR's declining membership was very noticeable, the event was still a celebration of Keokuk's and Iowa's participation in the Civil War. ${ }^{74}$

In 1938 Sioux City hosted the sixty-fourth state GAR encampment. Keokuk had used its final GAR encampment to celebrate its Civil War history, but in Sioux City the Journal focused on the inevitable end of the GAR when the last veteran died. The Journal expected about a dozen members to come to Sioux City, but only five attended. It ran articles about the disbanding of the GAR but expressed no emotion about its eventual fate. Instead, the Journal showed a mixture of detached curiosity and indifference toward the peculiar nature of a soon-to-be extinct fraternity. ${ }^{75}$ The reason for the indifference was that the Civil War was not a defining part of Sioux City's history, as it was in Keokuk. There were no obvious physical reminders of the Civil War in Sioux City, so it regarded the imminent extinction of the GAR and the decline of Civil War memory with resignation. When Civil War commemorations had been more vital civic occasions in the late nineteenth century, it was important for Sioux City residents to participate and link the city to the Civil War. During Memorial Day events, GAR encampments, and monument dedications from the 1880s to World War I, Sioux City, like other communities across former Union states, honored the veterans and deceased soldiers who had ended slavery and reunited the country. Unlike Keokuk, it could not boast of its role in the Civil War, but it could brag about what it had become after the Civil War. Sioux City residents, as a way to praise themselves during Civil War commemorations, claimed that their growth and affluence was an important outcome of the Civil War.

74. KDGC, 6/7/1926, 6/9/1926.

75. SCJ, 6/6/1938, 6/7/1938, 6/8/1938. 